\title{
Using a numerical model (PROTECH) to examine the impact of water transfers on phytoplankton dynamics in a Mediterranean reservoir
}

\author{
Enrique Moreno-Ostos ${ }^{1,3, *}$, J. Alex Elliott ${ }^{2}$, Luis Cruz-Pizarro $^{3}$, Carmelo Escot ${ }^{4}$, Ana Basanta $^{4}$ \\ and D. Glen George ${ }^{2}$
}

1 Flumen Research Group. Department of Ecology. University of Barcelona. Av. Diagonal 645. 08028. Barcelona (Spain).

2 Centre for Ecology and Hydrology. Lancaster Environment Centre. Library Avenue. Bailrigg LA1 4AP. Lancaster (UK).

3 Instituto del Agua. University of Granada. C/ Ramon y Cajal 4. 18071. Granada (Spain).

${ }^{4}$ Empresa Municipal de Abastecimiento y Saneamiento de Aguas de Sevilla (EMASESA). Escuelas Pías 1, 410 Sevilla (Spain).

* Corresponding author: emoreno@ub.edu

\begin{abstract}
Using a numerical model (PROTECH) to examine the impact of water transfers on phytoplankton dynamics in a Mediterranean reservoir

El Gergal is the last link in a system of reservoirs located in the Rivera de Huelva River, Seville (South-West Spain). Because of its position within the system and the different water transfer possibilities between reservoirs, the florisitic composition of phytoplankton in El Gergal can be strongly influenced by the concentration of cells present in the water transferred from other reservoirs in the series. In June 2000 a large Ceratium hirundinella inoculums was transferred from an upstream reservoir into El Gergal. The dinoflagellate inoculums entered in the receiving reservoir through the riverine zone depicting a marked horizontal structure, and inducing an intense summer bloom. Our results show that this Ceratium bloom was effective to compete and counteract the later development of the harmful cyanobacteria Aphanizomenon flos-aquae. Further, after the integration of a set of adaptations to the semi-arid Mediterranean region and subsequently validation, the PROTECH model (a 1D phytoplankton community model) was used to describe, assess and evaluate the potential impact on El Gergal phytoplankton dynamics of an alternative water transfer strategy. Finally, we encourage the use of dynamic modelling in lakes and reservoir management, as it constitutes a powerful tool that should offer reliable predictions and help managers in the usually difficult and complex task of adopting optimal decisions, in order to minimise water treatment costs and provide the best possible environmental quality.
\end{abstract}

Key words: Water transfer, reservoir system, El Gergal reservoir, PROTECH, dynamic modelling, phytoplankton succession.

\section{RESUMEN}

Aplicación de un modelo numérico (PROTECH) para analizar el impacto de trasvases de agua sobre la dinámica fitoplanctónica de un embalse mediterráneo

El Gergal ocupa la última posición dentro de la cadena de embalses ubicada sobre el río Rivera de Huelva (Sevilla, Sureste de España). Debido a su singular localización, El Gergal constituye el último receptor de una amplia gama de estrategias de trasvase de aguas. Como consecuencia, su comunidad fitoplanctónica presenta una dinámica espacio-temporal frecuentemente influida por la composición y la abundancia de microalgas en las aguas de trasvase. De esta manera, en junio de 2000 un trasvase de aguas desde el embalse de La Minilla a El Gergal propició el ingreso en éste de un importante inóculo del dinoflagelado Ceratium hirundinella a través de su zona fluvial. Una vez en El Gergal, Ceratium generó una marcada estructura horizontal y su población registró una intensa proliferación estival. Nuestros resultados sugieren que dicha proliferación de dinoflagelados repercutió de forma negativa en el posterior desarrollo de la cianobacteria Aphanizomenon flos-aquae. Además, tras la integración y validación de una serie de adaptaciones específicas para ecosistemas leníticos Mediterráneos, se aplicó el modelo numérico unidimensional de comunidad fitoplanctónica PROTECH para describir y evaluar el impacto potencial sobre la dinámica fitoplanctónica de El Gergal de una estrategia alternativa de trasvase de 
aguas. En este contexto, sugerimos el uso de modelos dinámicos como herramientas eficientes en la gestión integrada de embalses. Sin duda, su aplicación resultará de utilidad en la difícil y compleja tarea que supone adoptar decisiones que combinen la optimización de los costes de tratamiento del agua con el mantenimiento de una calidad ecológica adecuada.

Palabras clave: Trasvase de agua, sistema de embalses, embalse de El Gergal, PROTECH, modelos numéricos dinámicos, sucesión fitoplanctónica.

\section{INTRODUCTION}

Dam construction associated with water supply and power development projects has converted rivers throughout the world into regulated series of man-made reservoirs (Elser \& Kimmel, 1985). What makes reservoir series limnologically specific is the effect that the upstream reservoirs have on those below them. In a reservoir cascade, the top reservoir is usually not different from a solitary reservoir; the next and lower reservoirs, usually termed "cascade reservoirs", are all modified to some degree by the previous reservoirs in the sequence (Straskraba et al., 1993; Straskraba, 1994). Several studies have shown the positive effect that nutrient and sediment retention in the upstream reservoirs have on the water quality of the downstream ones (Dendy et al., 1973; Heinemann et al., 1973; Gloss et al., 1980; Gloss et al., 1981). Daley et al. (1981) calculated that 25-30\% of the decrease in Kootenay Lake (British Columbia) biological productivity was due to the presence of some upstream impoundments, and they also predicted that levels of phytoplankton and zooplankton would be reduced to less than a half of what they would have been had the dams not been constructed (Thorton et al., 1990). Straskraba (1994) concluded that water quality improves during its passage through a reservoir cascade.

Some authors have evaluated the influence of water discharges from the upper reservoirs on the nutrient availability for phytoplankton production in the downstream reservoirs (Martin \& Arneson, 1978; Gloss et al., 1980; Daley et al., 1981; Paulson \& Baker, 1981; Priscu et al., 1982). There also some studies describing the effect of upstream reservoirs on the thermal stratification conditions of the downstream one (Straskraba et al., 1973). However, in spite of

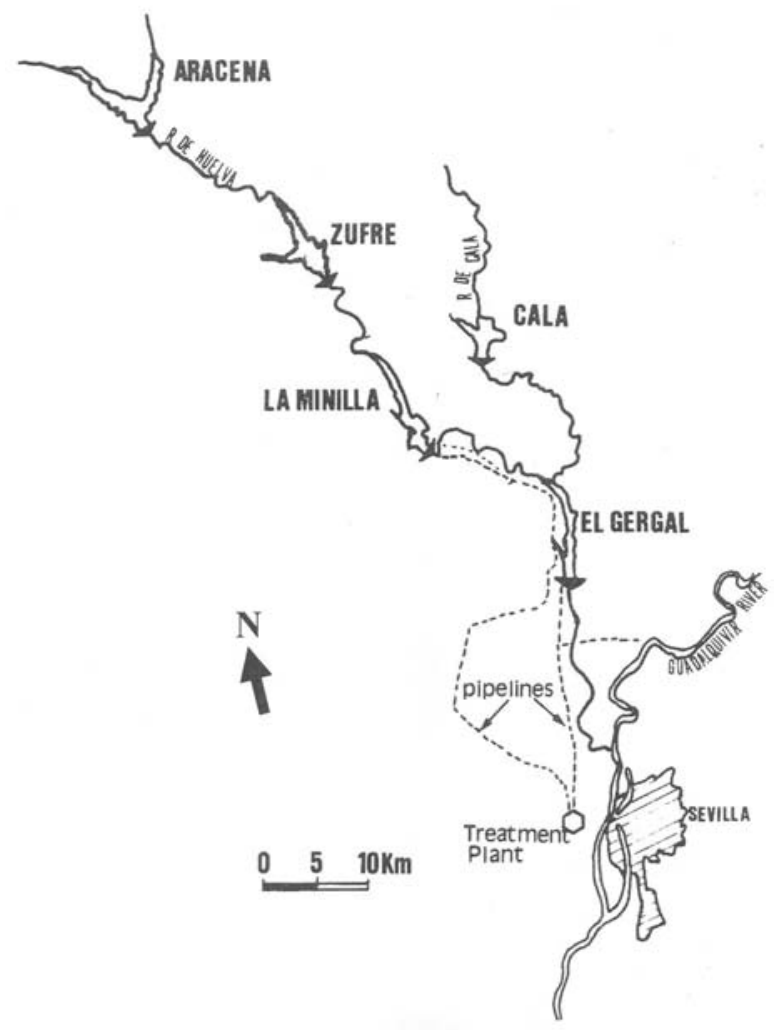

Figure 1. The reservoir network and some of the watertransfer options within El Gergal system (Modified from Toja $e t$ al., 1992). El sistema de embalses y algunas de las distintas opciones de trasvase de aguas. (Modificada de Toja et al., 1992).

its relevance for water quality management, there is a lack of research on the impact of shortterm algae inoculum from other reservoirs in the system on the phytoplankton composition and dynamics in the receiving reservoir.

In this paper we concentrate our attention on the impact of water transfers from an upstream reservoir in the cascade on the seasonal dynamics of phytoplankton in a water supply Mediterranean reservoir (El Gergal, South-West 
Spain). Further, we use dynamic modelling to simulate and assess the potential impact of an alternative water transfer strategy on the algae development in El Gergal.

\section{STUDY SITE}

El Gergal is the last in a chain of reservoirs (Aracena, Zufre, La Minilla and El Gergal) situated in the catchment of the Rivera de Huelva river, Seville (Spain) (Fig. 1) and supplies water for domestic, commercial and industrial use to an area which includes the city of Seville and twelve of its surrounding towns (ca. 1.3 million inhabitants). A fifth reservoir (Cala), located on a tributary to the Rivera de Huelva, completes the network and is primarily used to generate hydroelectric power. The complexity of the system and the location of El Gergal at the end of the network have profound consequences for the management of the reservoir (Toja et al., 1992; Galindo, 1998). El Gergal is usually described as a medium-size reservoir (Surface area: 250 ha; Volume: $35 \mathrm{hm}^{3}$; Maximum depth: $37 \mathrm{~m}$; Mean depth: $15.7 \mathrm{~m}$ ) but both the area and the volume can be severely reduced during dry periods. Estimated retention times thus vary from a minimum of twenty days during very wet periods to a maximum of one year during severe droughts.

El Gergal is a relatively deep reservoir and typically remains thermally stratified from the end of February to the middle of October. During June, and especially in July and August, a well defined thermocline develops at depths between 5 and $10 \mathrm{~m}$. The only period of complete isothermy occurs at the end of autumn and early winter.

Table 1 shows values for some water qualityrelated variables. These include the average concentration of chlorophyll- $a$ in the reservoir, a measure of the transparency of the water column (Secchi depth) and a number of chemical measurements. High concentrations of chlorophyll$a$ are periodically recorded during the summer, when the water column is stratified and nitrogen limitation stimulates the growth of nitrogenfixing cyanobacteria (Galindo, 1998), as Aphanizomenon flos-aquae and Anabaena sp.

\section{MATERIAL AND METHODS}

\section{Field and analytical methods}

Sampling took place from late April to October 2000 at weekly intervals at a station located in the deepest point of the lacustrine area of the reservoir. Vertical distribution of water temperature was measured using a YSI Model 58 probe. Water samples were taken with 5-L Van Dorn sampler from regular intervals within the water column and were analysed for chlorophyll $a$ and nutrients. Phytoplankton density was de-

Table 1. General water quality characteristics in El Gergal reservoir (January 1979-November 2002). Características generales de la calidad del agua en el embalse de El Gergal (Enero 1979-Noviembre 2002).

\begin{tabular}{|c|c|c|c|}
\hline Variable & Mean & Minimum & Maximum \\
\hline Temperature $\left({ }^{\circ} \mathbf{C}\right)$ & 16.53 & 8.00 & 28.80 \\
\hline pH & 7.51 & 6.22 & 9.91 \\
\hline Conductivity $\left(\mu \mathrm{S} \mathrm{cm} \mathbf{~ c m}^{-1}\right)$ & 282.55 & 114.00 & 1850.00 \\
\hline Dissolved Oxygen $\left(\mathrm{mg} \mathrm{l}^{-1}\right)$ & 5.85 & 0.01 & 17.24 \\
\hline Turbidity (NTU) & 11.35 & 0.40 & 290.00 \\
\hline Color (mg Pt-Co $\left.{ }^{-1}\right)$ & 16.88 & 1.00 & 72.00 \\
\hline Nitrate $\left(\mathrm{mg} \mathrm{NO}_{3}^{-} \mathrm{I}^{-1}\right)$ & 2.64 & 0.001 & 23.42 \\
\hline Dissolved Phosphorous ( $\mathrm{mg} \mathrm{PO}_{4}^{3-} \mathrm{I}^{-1}$ ) & 0.13 & 0.001 & 8.96 \\
\hline Chlorophyll- $a\left(\mu \mathrm{g} \mathrm{l}^{-1}\right)$ & 12.78 & 0.06 & 493.00 \\
\hline Secchi depth (m) & 1.8 & 0.2 & 8.0 \\
\hline
\end{tabular}


rived from counting according to the Utermöhl method in the lugol-fixed samples (Utermöhl, 1958). Phytoplankton species chlorophyll- $a$ content was estimated from density values using appropriate biometrical and physiological references (McLachlan, 1963; Baker, 1981; Kovacik \& Holeckova, 1984; Reynolds, 1984). Eventually (i.e. during the water transfer occurrence) surface phytoplankton biomass was continuously determined using in vivo fluorometry (Minitracka Fluorometer, Chelsea Instruments) along longitudinal transects. Both sampling and analysis were carried out by the Seville Water Supply Company (EMASESA) within their Programme of Water Supply Reservoirs Monitoring for Seville.

\section{Modelling methods}

PROTECH (Phytoplankton RespOnses To Environmental CHange) is a model that simulates the dynamics of multiple phytoplankton populations in lakes and reservoirs (Reynolds et al., 2001). Its distinct advantage over similar models is its unique ability to simulate the relative composition of the algal community, allowing both quantitative and qualitative conclusions to be drawn.

PROTECH was primarily applied to lakes and reservoirs in Northern Europe (e.g. Elliott et al., 2000; Reynolds et al., 2000). Recently, the model has been applied to water bodies in lower latitudes, including Australia (Lewis et al., 2002) and, for the present paper, Spain.

At the heart of PROTECH is the basic state variable equation determining the daily change in the chlorophyll $a$ concentration $\left(X, \mu \mathrm{g}^{-1}\right)$ of each phytoplankton life-form:

$$
\frac{\Delta X}{\Delta t}=\left(r^{\prime}-S-G-D\right) X
$$

where $r^{\prime}$ is the life-form specific growth rate defined as a proportional increase over the PROTECH time step $t(=24 \mathrm{~h}), S$ is the lifeform specific rate of loss due to settling out of the water column, $G$ is the rate of loss due to grazing (in the model species with a maximum linear dimension $>50 \mu \mathrm{m}$ are not grazed) and $D$ is the rate of loss caused by dilution due to the inflow and outflow of water within the lake. The routine is repeated for each of up to, usually, eight species, with daily iterations and with the opportunity to vary initial inoculum size. The growth rate $\left(r^{\prime}, d^{-1}\right)$ is further defined by:

$$
r^{\prime}=\min \left\{r_{(\theta, I)}^{\prime}, r_{\mathrm{P}}^{\prime}, r_{\mathrm{N}}^{\prime}, r_{\mathrm{Si}}^{\prime}\right\}
$$

where $r_{(\theta, I)}^{\prime}$ is the growth rate due to temperature and daily photoperiod $\left(r_{(\theta, I)}^{\prime}\right.$ is further adjusted to include dark respiration) and $r_{\mathrm{P}}^{\prime}, r_{\mathrm{N}}^{\prime}, r_{\mathrm{Si}}^{\prime}$ are the growth rates determined by phosphorus, nitrogen and silicon concentrations.

The physical side of the model divides the simulated water body into $0.1 \mathrm{~m}$ layers, which are adjusted in volume and surface area to reflect the morphology of the basin. An initial profile for the water column (containing temperature, nutrient concentrations and inoculum sizes for the algae) is defined for day 1. Daily wind speed, cloud cover, river inflow (including nutrient concentrations) and outflow data are input to the model and insolation is adjusted according to the day of the year and latitude. For each 24-hour time-step, the Monin-Obukhov equation is used to calculate the mixed layer thickness as a function of heat flux and wind stirring on a given day (Imberger \& Hamblin, 1982). The starting water column profiles of temperature, nutrients and phytoplankton are changed at the start of each time-step as a result of mixed layer changes. Biological functions are then used to calculate the new biomass and dissolved nutrient concentrations at the end of the time-step, assuming no further vertical movements. More detailed descriptions of the equations involved can by found in Reynolds et al. (2001).

\section{PROTECH adaptation and calibration for Mediterranean reservoirs}

Before the application of PROTECH to El Gergal some adaptations to Mediterranean semiarid region were adopted, specifically regarding the surface water energy-flux calculations. The model already calculated the daily incoming solar radiation for a given latitude, but used 
some equations specific to Northern Europe latitudes to calculate the energy loss from the water surface to the air. Thus, the following modifications to the PROTECH code were made using information in Gill (1982):

Firstly, an equation was added calculating the mass of water lost by evaporation processes $(E)$ :

$$
E=\rho_{a} c_{E} u\left(q_{s}-q_{a}\right)
$$

where $\rho_{a}$ is the density of air, $c_{E}$ is a specific constant, $u$ is wind speed, $q_{s}$ is the specific humidity at the water-surface and $q_{a}$ is the specific humidity of the air.

Next, the upward heat flux $\left(Q_{s}\right)$ was calculated as:

$$
Q_{s}=\rho_{a} c_{p} c_{H} u\left(T_{s}-T_{a}\right)
$$

where $c_{p}$ is the specific heat capacity of air, $c_{H}$ is a dimensionless coefficient, $T_{s}$ is the surface water temperature and $T_{a}$ is the air temperature; both are measured in Kelvin.

Finally, the net radiant heat flux $\left(Q_{B}\right)$ was calculated by:

$$
Q_{B}=0.985 \sigma T_{s}^{4}\left(0.39-0.05 e_{a}^{1 / 2}\right)\left(1-0.6 n_{c}^{2}\right)
$$

where $\sigma$ is the Stefan-Boltzmann constant, $e_{a}$ is the vapour pressure of water and $n_{c}$ is fraction of the sky covered by cloud.

Thus, energy loss from the water surface to the air $\left(Q_{\text {Loss }}\right)$ was now calculated by:

$$
Q_{\mathrm{Loss}}=L_{v} E+Q_{s}+Q_{B}
$$

where $L_{v}$ is the latent heat of vaporization of water. By using the above equations, the energy budget of El Gergal was described correctly

One final adaptation was made to the model to simulate the internal release of soluble reactive phosphorus (SRP) from the littoral and benthic zones. SRP concentrations measured by EMASESA over 2000 and 2001 were used as a guide to how much extra SRP was needed to be added to the simulated water column. Thus, between June-August, $50 \mu \mathrm{g} \mathrm{l}^{-1}$ SRP was added to the water column between the bottom and $20 \mathrm{~m}$ from the bottom (representing the approximate hypolimnion).

In the present paper, PROTECH is used to investigate and to assess the potential impact of water transfer from upstream reservoirs on the phytoplankton dynamics in El Gergal resevoir. Input and validation data were gathered from on-shore meteorological stations (wind speed, incoming solar radiation, air temperature), the regular sampling programme of EMASESA (chlorophyll$a$ concentration, phytoplankton counts, nutrient concentrations, inflow/outflow rates) and the Automatic Water Quality Monitoring Station (AWQMS) on El Gergal (Rouen, 2003). Also, concentrations of Ceratium hirundinella in La Minilla reservoir were used to create the extra inoculums and a new piece of code was written to add this inoculums into the epilimnion during the period in which La Minilla was used as a source of water for El Gergal. As PROTECH is a $1 \mathrm{D}$ model and the inoculums effect was manifestly a $3 \mathrm{D}$ process, the Ceratium biomass was calibrated and simulated both for the riverine and the lacustrine zone. Consequently, a complete view of the water transfer impact on the dinoflagellate population dynamics was achieved.

After making these specific changes to the generic PROTECH model, the simulated chlorophyll- $a$ evolution (measured in the top $5 \mathrm{~m}$ of the water column) corresponding to the two main phytoplankton species present in El Gergal during Summer 2000, Ceratium hirundinella (Fig. 2a) and Aphanizomenon flos-aquae (Fig. b) matched successfully the observed values.

\section{RESULTS}

\section{Water transfers and Ceratium hirundinella inoculums to El Gergal}

One important factor influencing the floristic composition of phytoplankton in El Gergal is the concentration of cells present in the water transferred from other reservoirs upstream in the system. This inoculums effect was especially notable in early June 2000 when a epilimnetic maximum of the dinoflagellate Ceratium hirundi- 


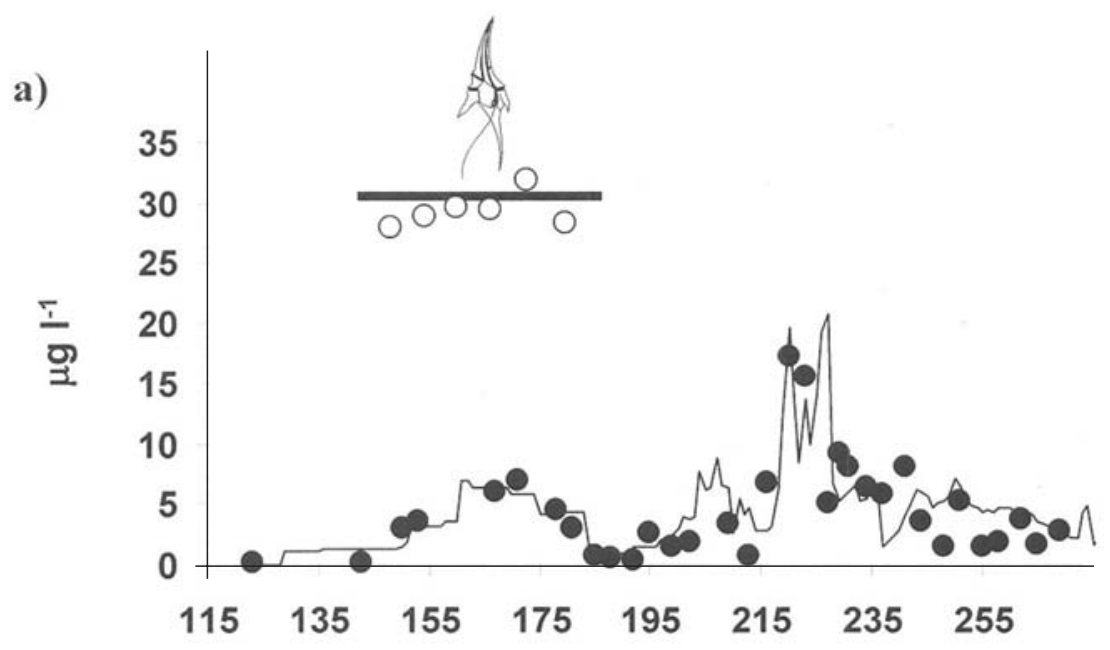

b)

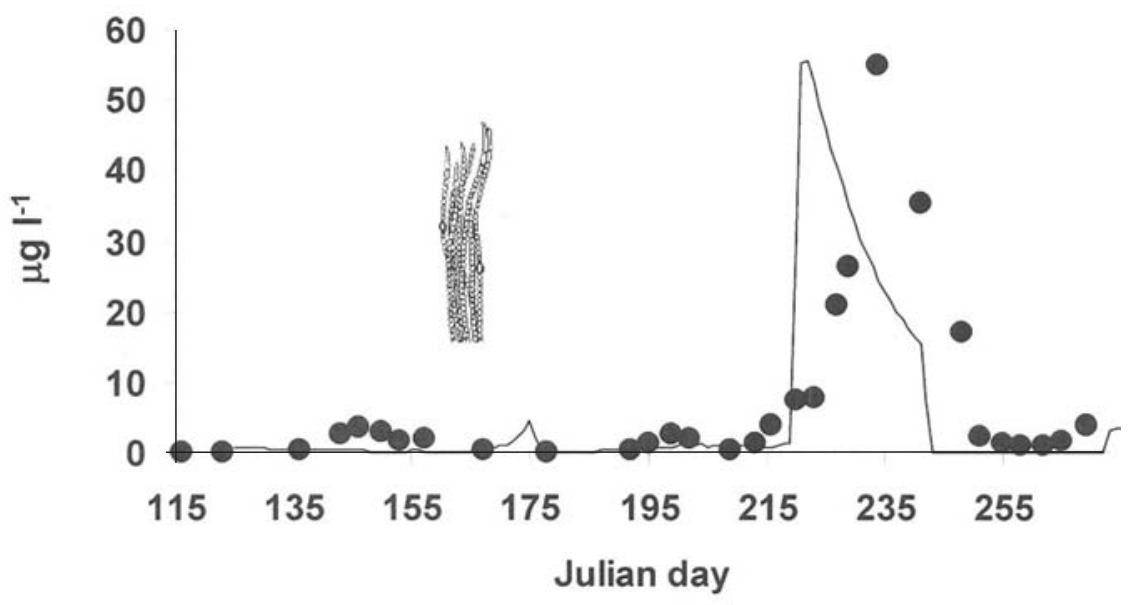

Figure 2. (a) Observed (black circles) and PROTECH simulated (line) temporal evolution of Ceratium hirundinella biomass ( $\mu$ g $1^{-1}$ ) in the top 5 meters of El Gergal lacustrine zone during the study period. The observed (empty dots) and simulated (horizontal bar). Ceratium concentration $\left(\mu \mathrm{g} \mathrm{l}^{-1}\right)$ in the riverine zone of El Gergal are also shown. (b) Observed (circles) and PROTECH simulated (line) temporal evolution of Aphanizomenon flos-aquae biomass $\left(\mu \mathrm{g} \mathrm{l}^{-1}\right)$ in the top 5 meters of El Gergal reservoir. (a) Evolución temporal observada (círculos negros) y simulada por PROTECH (línea) de la biomasa de Ceratium hirundinella ( $\mu g l^{-1}$ ) en los 5 primeros metros de la columna de agua en la zona lacustre de El Gergal. Se muestran igualmente los valores observados (circulos vacios) y simulados (barra horizontal) de la concentración de Ceratium ( $\left.\mu \mathrm{g} l^{-1}\right)$ en la zona fluvial del embalse. (b) Evolución temporal observada (círculos negros) y simulada por PROTECH (línea) de la biomasa de Aphanizomenon flos-aquae ( $\mu \mathrm{g} l^{-1}$ ) en los 5 primeros metros de la columna de agua de El Gergal.

nella was observed in the upstream La Minilla reservoir (Fig. 3a) and a large amount of water was transfered from La Minilla to El Gergal. Subsequently, this inoculum gave rise to a summer maximum of Ceratium in the main basin of El Gergal in July and August (Fig. 3b).

A detailed analysis of the horizontal distribu- tion of phytoplankton in the longitudinal axis of El Gergal during the water transfer period showed a well defined North to South gradient of $\mathrm{Ce}$ ratium (Fig. 4). In most situations, such as those described by Heaney (1976), George \& Heaney (1978), Harris et al. (1979), and Heaney \& Talling (1980) such aggregations are the results of 
the organisms' response to wind-induced water movements. In this case, the spatial structure was directly related to the influx of Ceratium from La Minilla where the highest surface concentrations were observed in the upper riverine zone.

\section{Modelling the impact of a different water transfer strategy on phytoplankton dynamics in El Gergal reservoir}

Next, we use PROTECH to simulate and to examine the potential impact in El Gergal phytoplankton dynamics if the same water transfer was executed after the occurrence of the Ceratium bloom in La Minilla reservoir (i.e. during the first week in July).

Very different results evolved from this alternative hydraulic strategy. As can be observed in figure 5a, very low inoculums would enter in El Gergal as a consequence of this alternative water transfer. As a result, the $\mathrm{Ce}$ ratium Spring growth in El Gergal would be, unsurprisingly, suppressed and Ceratium population would generally present low biomass until mid July (around day 200).

The main feature in this scenario is the hypothetical large Aphanizomenon bloom which occurs from the middle of August (around day 225) and persists through September, reaching maximum chlorophyll- $a$ concentration of around $90 \mu \mathrm{g} \mathrm{l}^{-1}$ (Fig. 5b).

The reason why the two different hydraulic regimes examined resulted in such a different algae succession can be found in the nutrient depletion originated by Ceratium during June 2000 in El Gergal epilimnion. Ceratium typically develops a population with a low specific productivity and a long generation time; thus
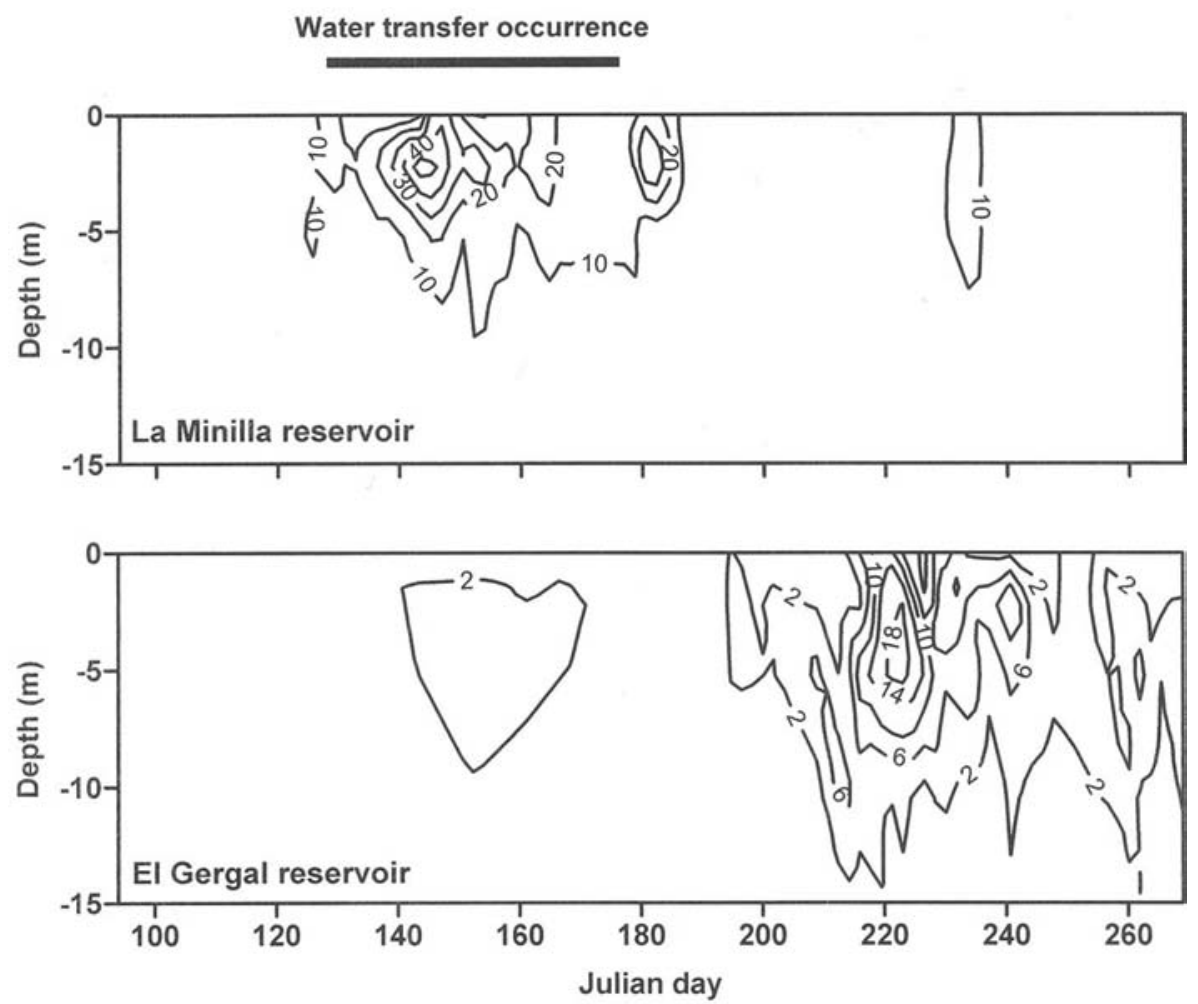

Figure 3. The temporal variation of Ceratium hirundinella biomass $\left(\mu \mathrm{g} \mathrm{l}^{-1}\right)$ in the top 15 meters of (a) La Minilla reservoir and (b) El Gergal reservoir. The horizontal bar shows the period when a large volume of water was transferred into El Gergal from La Minilla. Variación temporal de la biomasa de Ceratium hirundinella $\left(\mu \mathrm{g}^{-1}\right)$ en los primeros 15 metros de (a) el embalse de La Minilla y (b) el embalse de El Gergal. La barra horizontal señala el periodo de trasvase de aguas desde La Minilla a El Gergal. 


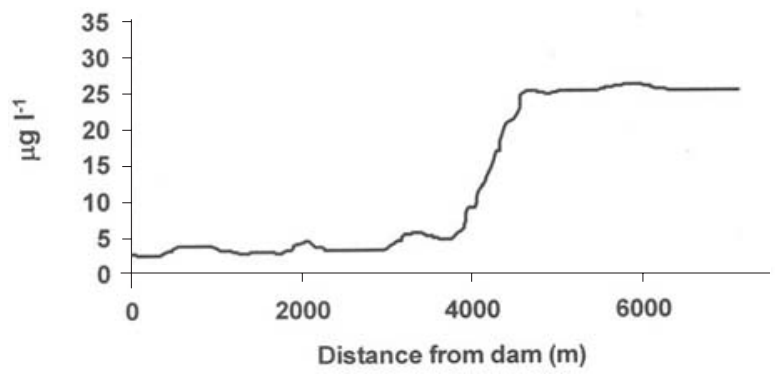

Figure 4. Longitudinal transect showing the horizontal distribution of Ceratium hirundinella biomass (expressed as chlorophyll- $a$ content, $\mu \mathrm{g}^{-1}$ ) in El Gergal reservoir following the water transfer from La Minilla. Distribución horizontal de la biomasa de Ceratium hirundinella (expresada como concentración de clorofila- $a, \mu g l^{-1}$ ) a lo largo de un transecto longitudinal en el embalse de El Gergal tras efectuarse el trasvase de aguas desde La Minilla.

they inmobilize large amounts of nutrients and slow down the overall activity of the ecosystem (Serruya et al., 1980).

The average SRP concentration in the top $5 \mathrm{~m}$ of El Gergal was reduced from May to June 2000 by approximately $85 \%$, coinciding with the entrance and growth of Ceratium inoculums (EMASESA, unpublished data). After that, SRP remained relatively low and only a moderate Aphanizomenon bloom could be sustained in August.

By contrast, if the alternative withdrawal strategy was adopted, and water from La Minilla were transferred into El Gergal after the Ceratium bloom occurrence, the reduced Ceratium inoculums now introduced would have a lower impact on SRP concentration and, as predicted by PROTECH, a large and durable Aphanizomenon flos-aquae bloom would occur during August.

It has been previously demonstrated that in most freshwater habitats physically amenable to cyanobacterial growth, phosphorous availability often dictates magnitudes of dominance and bloom formation (Healey, 1982).

\section{DISCUSSION}

Although the long-term consequences of being the last link of a whole chain of reservoirs are well known and points to generalized water a)

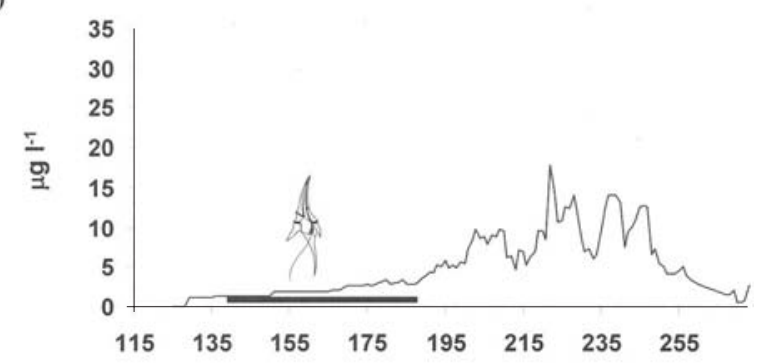

b)

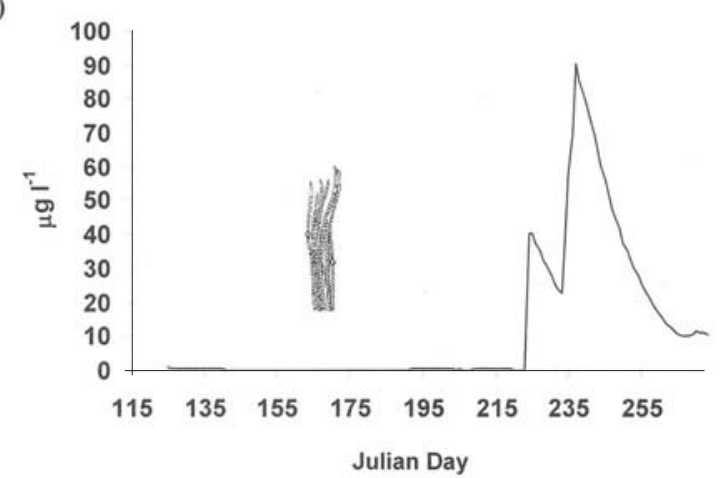

Figure 5. (a) Simulated temporal dynamics of Ceratium hirundinella in El Gergal reservoir if the water transfer from La Minilla reservoir was developed after the occurrence of the Ceratium bloom. (b) The same scenario for Aphanizomenon flos-aquae biomass $\left(\mu \mathrm{g}^{-1}\right)$. (a) Simulación de la dinámica temporal de Ceratium hirundinella en El Gergal considerando que el trasvase de agua se hubiera efectuado tras la desaparición del bloom de Ceratium hirundinella en La Minilla. (b) El mismo escenario para la biomasa de Aphanizomenon flos-aquae $\left(\mu g l^{-1}\right)$.

quality improvements (Margalef et al., 1976; Gloss et al., 1980; Gloss et al., 1981; Daley et al., 1981; Evans \& Paulson, 1983; Thorton et al., 1990; Mineeva, 1995), our results demonstrate that there are also some shortterm processes occurring inside the reservoirs system as a consequence of water transfer that can strongly influence the water quality in the receiving reservoir. Among those processes is especially remarkable the algal inoculums effect, as it constitutes an important way for harmful algae to spread along the whole reservoir chain. Primachenko (1981) demonstrated for the Dnipier cascade of reservoirs the development of intensive blooms in inter-cascade position water bodies as a consequence of the discharge of algae from reservoirs upstream. 
In the above sections we have shown how $\mathrm{Ce}$ ratium hirundinella, a previously non-dominant species in El Gergal, became an important component in its phytoplankton dynamics after being inoculated by a water transfer from a Ceratium-rich upstream reservoir. In agreement with Gordyn (1989) our results show that once the inoculums reaches the receiving reservoir, it depicts a very strong horizontal structure, decreasing in concentration from the influx riverine zone to the far lacustrine area. This spatial heterogeneity and its ecological importance (George, 1981; Legendre \& Demers, 1984) points to the necessity of extensive surveys along the reservoirs horizontal axis, in order to improve our understanding on water quality dynamics and its application to optimal water bodies management.

In our case study, PROTECH simulations confirm that the adopted water transfer strategy was optimal as the induced competition between dinoflagellates and cyanobacteria resulted in a moderate Aphanizomenon summer bloom. If the alternative strategy had been adopted, PROTECH predict the occurrence of a large, undesirable and potentially harmful Aphanizomenon bloom.

Multiple-reservoir system management constitutes an especially difficult task in the semiarid Mediterranean region, and water supply requirements during the long dry season could force to adopt hydraulic strategies which sometimes could work against water quality. Thus, a deep limnological knowledge on their reservoirs constitutes managers' main way to reach the objective of providing both water quantity and quality. In this context, management models should offer reliable predictions of the outcome of alternative approaches to problems which assist the manager to decide the optimal course of action (Reynods, 1999). Good limnological and engineering management of reservoir water quality may be facilitated by the availability of good and proven mathematical models (Reckhow \& Chapra, 1983; Henderson-Sellers, 1984; Henderson-Sellers, 1993).

PROTECH constitutes a powerful tool in hands of reservoir managers to produce day-today predictions of the quality characteristics of the water so that appropriate decisions can be assessed in order to minimise treatment costs and provide the best possible environmental quality. PROTECH has successfully been applied to many water bodies over the last 10 years and, through a combination of extremely detailed data provided by EMASESA and new coding in the model, a Mediterranean reservoir, El Gergal, can now be added to that list. Through the simulations mentioned above, a greater understanding of the influence of hydraulic management on the phytoplankton dynamics in this complex ecosystem has been gained.

Thorton et al. (1990) pointed out that because of the potential value of integrating multiplereservoir operational and scheduling practices with reservoir water quality management objectives, further research to determine the influence of inter-reservoir transfer on biological productivity in multiple-reservoir series is needed. The present paper advances this goal, suggesting a dynamic model-based management strategy in the context of the limnological dynamics resulting from catchment-level and basin-level operations.

\section{ACKNOWLEDGEMENTS}

This paper has been partly funded by the Projects UE-LIFE 98 ENV/UK/000607 and CICYT HID 99-0836. We are also grateful to EMASESA for providing reservoirs data and sampling facilities. E. Moreno-Ostos was founded by a University of Granada Research Programme Postdoctoral Contract.

\section{REFERENCES}

BAKER, K. K. 1981. Ecology and taxonomy of five natural populations of the genus Aphanizomenon Morren (Cyanophyceae). Arch. Hydrobiol., 92: 222-251.

DALEY, R. J., E. C. CARMACK, C. B. J. GRAY, C. H. PHARO, S. JASPER \& R. C. WIEGAND 1981.The effects of upstream impoundments on the limnology of Kootenay Lake. B.C.Environment Council Scientific Reports. B.C. Vancouver. 117 pp.

DENDY, F. E., W. A. CHAMPION \& R. B. WILSON. 1973. Reservoir sedimentation surveys in 
the United States. In: Man-made lakes: Their problems and environmental effects. Ackerman, W. C., G. F. White \& E. B. Worthington (eds.): 349-358. American Geophysical Union, Washington D.C.

ELLIOTT, J. A., A. E. IRISH, C. S. REYNOLDS \& P. TETT. 2000. Modelling freshwater phytoplankton communities; an exercise in validation. Ecol. Model., 128: 19-26.

ELSER, J. J. \& B. L. KIMMEL 1985. Nutrient availability for phytoplankton production in a multiple-impoundment series. Can. J. Fish. Aquat. Sci., 42: 1359-1370.

EVANS, T. D. \& L. J., PAULSON. 1983. The influence of Lake Powell on the suspended sedimentphosphorous dynamics of the Colorado River inflow to Lake Mead. In: Aquatic resources management of the Colorado River ecosystem. Adams, V. D \& V. A. LaMarra (eds.): 57-68. Ann Arbor Science, Ann Arbor, MI.

GALINDO, M. D. 1998. Funcionamiento del embalse de El Gergal: Balance de nutrientes. Ph.D. Thesis. Universidad de Sevilla, $250 \mathrm{pp}$.

GEORGE, D. G. \& I. HEANEY. 1978. Factors influencing the spatial distribution of phytoplankton in a small productive lake. J. Ecol., 66: 133-155.

GEORGE, D. G. (1981). Zooplankton patchiness. Reports of the Freshwater Biological. Association, 49: 33-44.

GILL, A. E. 1982. Atmosphere-Ocean dynamics. Academic Press, San Diego. 662 pp.

GLOSS, S. P., L. M. MAYER \& D. E. KIDD .1980. Advective control of nutrient dynamics in the epilimnion of a large reservoir. Limnol. Oceanogr., 25: 219-228.

GLOSS, S. P., R. C. REYNOLDS, L. M. MAYER \& D. E. KIDD. 1981. Reservoir influences on salinity and nutrient fluxes in the arid Colorado River basin. In: Proceedings of the symposium on surface water impoundments. H. G. Stefan (ed.): 16181629. American Society of Civil Engineering. New York.

GORDYN, R. 1989. Phytoplankton of the Radunia River in a cascade of small reservoirs. Arch. Hydrobiol., 33: 389-396.

HARRIS, G. P., S. I. HEANEY \& J. F. TALLING. 1979. Physiological and environmental constraints in the ecology of the planktonic dinoflagellate $\mathrm{Ce}$ ratium hirundinella. Freshwat. Biol., 9: 413-428.

HEALEY, M.C. 1982. Phosphate. In: The biology of Cyanobacteria. Carr, N. G. \& B. A. Whitton (eds.): 105-124. Blacwell Scientific. Oxford.
HEANEY, S. I. 1976. Temporal and spatial distribution of the dinoflagellate Ceratium hirundinella $\mathrm{O}$. F. Müller within a small productive lake. Freshwat. Biol., 6: 531-542.

HEANEY, S. I. \& J. F. TALLING. 1980. Dynamic aspects of dinoflagellate distribution patterns in a small productive lake. J. Ecol., 68: 75-94.

HEINEMANN, H. G., R. F. HOLT \& D. L. RAUSCH. 1973. Sediment and nutrient research on selected corn belt reservoirs. In: Man-made lakes: Their problems and environmental effects. Ackerman, W. C., G. F. White \& E. B. Worthington (eds.): 381-386. American Geophysical Union, Washington D. C.

HENDERSON-SELLERS, B. $1984 . \quad$ Engineering Limnology. Pitman, London. 356 pp.

HENDERSON-SELLERS, B. 1993. A hierarchy of mathematical models: towards understanding the physical processes in reservoirs. In: Comparative reservoir limnology and water quality management. Straskraba, M., J. G. Tundisi \& A. Duncan (eds.): 93-97. Developments in Hydrobiology. Kluwer Academic Publishers. The Netherlands.

IMBERGER, J. \& P. F. HAMBLIN. 1982. Dynamics of lakes, reservoir and cooling ponds. Ann. Rev. Fluid Mech., 14: 153-187.

KOVACIK, L. \& H. HOLECKOVA. 1984. Biometric evaluation of populations of phanizomenon flosaquae from Trebon pond basin (Czechoslovakia). Arch. Hydrobiol. Supp., 67: 283-298.

LEGENDRE, L. \& S. DEMERS. 1984. Towards dynamic biological oceanography and limnology. Can. J. Fish. Aquat. Sci., 41: 2-19.

LEWIS, D. M., J. A. ELLIOTT, M. F. LAMBERT \& C. S. REYNOLDS. 2002. The simulation of an Australian reservoir using a phytoplankton community model (PROTECH). Ecol. Model., 150: 107-116.

MARGALEF, R., D. PLANAS, J. ARMENGOL, A. VIDAL, N. PRAT, A. GISET, J. TOJA \& M. ESTRADA. 1976. Limnologia de los embalses españoles. Dirección General de Obras Hidráulicas, Ministerio de Obras Públicas. Madrid. 422 pp.

MARTIN, D. B. \& R. D. ANDERSON. 1978. Comparative limnology of a deep-discharge reservoir and a surface-discharge lake on the Madison River, Montana. Freshwat. Biol., 8: 33-42.

MCLACHLAN, J., U. T. HAMMER \& P. R. GORHAM. 1963. Observations on the growth and colony habits of ten strains of Aphanizomenon flosaquae. Phycologia, 2: 157-168. 
MINEEVA, N. M. (1995). Formation of primary production in the reservoirs of the Volga chain of hydroelectric stations under present conditions: Phytoplankton pigments. Wat. Res., 22: 694-704.

PAULSON, L. J. \& J. R. BAKER. 1981. Nutrient interactions among reservoirs on the Colorado River. In: Proceedings of the symposium on surface water impoundments. H.G. Stefan (ed.): 1647-1658 American Society of Civil Engineering. New York.

PRIMACHENKO, A. D. 1981. Phytoplankton and primary production of the Dnieper and its reservoirs. Naukova Dumka, Kiev. 256 pp.

PRISCU, J. C., J. VERDUIN \& J. E. DEACON. 1982. Primary productivity and nutrient balance in a lower Colorado River reservoir. Arch. Hydrobiol., 94: 1-23.

RECKHOW, K. H. \& S. C. CHAPRA. 1983. Engineering Approaches for lake management. Vol. 1: Data analysis and empirical modelling. Butterworth Publishers. Boston, M. A. 340 pp.

REYNOLDS, C. S. (1984). The ecology of freshwater phytoplankton. Cambridge University Press. Cambridge. 384 pp.

REYNOLDS, C. S. (1999). Modelling phytoplankton dynamics and its application to lake management. In: The ecological bases for lake and reservoir management. Harper, D. M., B. Brierley, A. J. D. Ferguson \& G. Phillips (eds.): 123-131. Developments in Hydrobiology. Kluwer, The Netherlands.

REYNOLDS, C. S., A. E. IRISH \& J. A. ELLIOTT. 2000. Simulations of phytoplankton growth in Sjon Erken. Report to EU REFLECT Programme.

REYNOLDS, C. S., A. E. IRISH \& J. A. ELLIOTT. 2001. The ecological basis for simulating phy- toplankton responses to environmental change (PROTECH). Ecol. Model., 140: 271-291.

ROUEN, M. 2003. Using an automatic monitoring station to assess the impact of episodic mixing on the seasonal succession of phytoplankton. Ver. Internat. Verein. Limnol., 27: 2972-2976.

SERRUYA, C., M. GOPHEN \& U. POLLINGHER. 1980. Lake Kinneret: Carbon flow patterns and ecosystem management. Arch. Hydrobiol., 88: 265-302.

STRASKRABA, M. J. 1994. Vlatava cascade as teaching grounds for reservoir limnology. Wat. Sci. Technol., 30: 289-297.

STRASKRABA, M., J. HRBACEK \& P. JAVORNICKY. 1973. Effect of an upstream reservoir on the stratification conditions in Slapy reservoir. In: $\mathrm{Hy}$ drobiological studies 2. Hrbacek, J. \& M. Straskraba (eds): 7-82. Prague.

STRASKRABA, M., J. G. TUNDISI \& A. DUNCAN. 1993. State-of-the-art of reservoir limnology and water quality management. In: Comparative reservoir limnology and water quality management. Straskraba, M., J. G. Tundisi \& A. Duncan (eds): 213-288. Kluwer Academic Publishers. The Netherlands.

THORTON, K. W., B. L. KIMMEL \& F. E. PAYNE. 1990. Reservoir Limnology. Ecological perspectives. John Wiley \& Sons, Inc. New York. 246 pp.

TOJA, J., A. BASANTA, R. FERNÁNDEZ ALES. 1992. Factors controlling algal biomass in the complex of water supply reservoirs of Sevilla (Spain). Limnetica, 8: 267-277.

UTERMÖL, H. 1958. Zur Vervollkomrnnung ver quantitativen phytoplankton methodic. Mitt. Int. Verein. Limnol., 9: 1-38. 
